\title{
Ulerythema Ophryogenes and Atopy
}

\section{R.L.J. Mertens}

\section{Geel}

Author's address: R. L. J. Mertens, Collegestraat 55, Geel (Belgium)

In 15 patients from 5 different family's with ulerythema ophryogenes strong indications for an atopic constitution were found.

Most patients had a personal anamnesis with atopic dermatitis, hay fever or asthma, many of their family were atopic.

They had strongly positive reactions on intracutaneous injection of inhalation allergens.

Familie III

$\mathrm{O}$

$?$

$? \tau ?$

$\mathrm{n}$

d-r-O

0, o

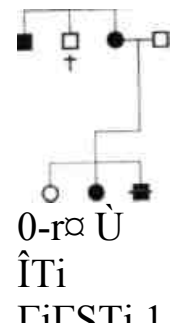

Fíg.1

(C) П Ulerythema ophryogenes $\bullet$ Atopie - Keratosis pilaris

From the geneologic table of one of the families (Fig. 1) it is evident that ulerythema ophryogenes just as keratosis pilaris and atopy depends on an irregular dominant gene.

The genetic defect responsible for ulerythema ophryogenes might be identical or narrowly linked with the defect responsible for atopy.

* Formerly assistant at the Department of Dermatology, Catholic University, Nijmegen. 